\title{
Alchemy and the Renaissance Commentary Tradition on Meteorologica IV
}

\author{
CRAIG MARTIN
}

Villa I Tatti, Florence

\begin{abstract}
It has been well noted that Aristotle's Meteorologica IV has played an important role in the development of alchemy because of its quasi-corpuscularian doctrines and its treatments of art and nature. This paper uncovers to what extent Renaissance commentaries on this book took into account alchemy. Many Renaissance commentators such as Agostino Nifo, Lodovico Boccadiferro and Cesare Cremonini were skeptical of the possibility of the transmutation of metals and limited their discussions to what they found in medieval commentaries. Several scholars, however, noted the utility of this book towards alchemy. By the middle of the seventeenth century, two commentators intertwined their interpretations with alchemy. Girolamo Trimarchi, following the Jesuit commentary tradition, considered this work primarily with respect to alchemy; and Niccolò Cabeo utilised alchemical experiments to guide his reading of the text and make Aristotle's work relevant to the emerging experimental natural philosophy.
\end{abstract}

\section{Introduction}

Ever since Frances Yates, there has been a widespread association of Neoplatonism and the rise of the occult sciences during the Renaissance. ${ }^{1}$ Thus the adoption of astrology, natural magic and the alchemy as new sciences is seen to be concurrent with the loosening of Aristotelianism's grip on intellectual life. Certainly, several notable proponents of natural magic and alchemy were also fervent anti-Aristotelians. Prominent examples, such as Paracelsus and Giordano Bruno, easily come to mind. Similarly, Thomas Erastus's attacks on Paracelsus used traditional Aristotelian natural philosophy as their foundation. ${ }^{2}$ Nevertheless just as the historical evidence does not confirm a simple split between Aristotelianism and the novel natural philosophies of the seventeenth centuries, ${ }^{3}$ we should not think that

${ }^{1}$ Yates influentially argued that Renaissance Neoplatonists interested in Hermetic writings and the occult sciences helped reduce the hegemonic position of Aristotelianism. See Frances Yates, Giordano Bruno and the Hermetic Tradition (London: Routledge, 1964).

${ }^{2}$ Cesare Vasoli, "Alchemy in the Seventeenth Century: The European and Italian Scene," in Reason, Experiment, and Mysticism, ed. William R. Shea (New York: Science History Publications, 1975), 49-58.

${ }^{3}$ For example, Dennis Des Chene, Physiologia: Natural Philosophy in Late Aristotelian and Cartesian Thought (Ithaca: Cornell University Press, 1996); Roger Ariew, Descartes and the Last Scholastics (Ithaca: Cornell University Press, 1999); Cees Leijenhorst, The Mechanisation of Aristotelianism: The Late Aristotelian Setting of Thomas Hobbes' Natural Philosophy (Leiden: Brill, 2002); Margaret Osler, "Renaissance Humanism, Lingering Aristotelianism and the New Natural Philosophy: Gassendi on Final Causes," in Humanism and Early Modern Philosophy, eds. Jill Kraye and M. W. F. Stone (London: Routledge, 2000) 193-208.

(C) Society for the History of Alchemy and Chemistry 2004 
medieval and Renaissance Aristotelians, that is those who wrote commentaries on the works of the Stagirite in the setting of universities, were uniformly against the claims of alchemists or their practices.

Aristotle's writings do not give a clear pronouncement on the possibility of the transformation of metals. The doctrine of the fixity of the species, which clearly applies to living creatures, is never explicitly declared to apply to metals. And despite the fact that Aristotle's life preceded the initial stages of alchemy and that no extant work specifically addressed the nature of metal or minerals, there is much in his writings that could be used in discussions of the possibility of the artificial transformation of metals. In Physics II.1, Aristotle makes distinctions between the natural and artificial; natural substances have internal sources of generation and change, while for artifacts this source exists externally. ${ }^{4}$ The production of natural and artificial objects is discussed in more detail in Metaphysics VII. Here Aristotle argues that there are some things, such as health, which are generated both through artifice and through spontaneity, that is by nature. ${ }^{5}$ Interpretations of these passages could potentially support the idea that metals could be made either by either artificial or natural mixtures. The nature of the formation of mixtures, i.e., a new substance that originates from the fusion of at least two others, is the subject of De generatione I.10. Here, Aristotle explains that substances mix more easily if small portions are juxtaposed between each other. Those substances, typically liquids, that are easily divided into small particles are more likely to mix. He gives the example of the mixture of bronze and tin. In this case, because tin is far more susceptible to division than bronze, the newly created mixture has far more of the properties of bronze than tin. ${ }^{6}$ Thus, metallurgical practices form a prime example of the creation of artificial mixtures.

Perhaps, the most relevant passages to alchemy from the Aristotelian corpus are those from Meteorologica IV and the final chapter of Meteorologica III. Meteorologica III.6 describes the formation of metals and minerals. According to Aristotle, metals are the product of a watery exhalation trapped deep below the surface of the earth, often times in stones. The aridity of this region compresses and congeals this watery substance into metals. The composition of metals from water explains their fusibility. ${ }^{7}$ Meteorologica IV does not treat meteorology but rather the nature and formation of homeomerous substances. Since metals are a prime example of homeomerity, many of the discussion of the passive qualities are applicable to metals.

Meteorologica IV, as well as the final chapter of Meteorologica III, despite their relatively sparse treatments of metals and their properties, became the loci classici for Aristotelian underpinnings of alchemical theory. From the reintroduction of Aristotle's writings into the Latin West in the twelfth and thirteenth centuries until the beginning of the seventeenth century, Aristotelian scholars and alchemists alike referred to Meteorologica IV as a source of alchemical knowledge, and commentators included discussions of alchemical subjects in their treatises on this book. ${ }^{8}$

4 192b11-192b23; 192b35-193a1.

5 1034a9-11.

6 328a32-328b14.

7 378a25-378b4.

${ }^{8}$ On the relation between alchemy and natural philosophy in the Middle Ages see Chiara Crisciani and Claude Gagnon, Alchimie et philosophie au moyen âge (Montreal: L'Aurore, 1980); Barbara Obrist, "Les rapports d'analogie entre philosophie et alchimie médiévale," in Alchimie et philosophie, eds. Jean-Claude Margolin and Sylvain Matton (Paris: J. Vrin, 1991), 43-64. 
It has been well demonstrated that alchemists appropriated Meteorologica IV both in the Middle Ages and the early modern period. The Summa perfectionis of [Ps.] Geber (13th c.) promoted a corpuscular Aristotelianism derived from the discussions of pores and particles in Meteorologica IV; 9 and Constantine of Pisa's Liber secretorum alchimie (ca. 1257) cited Meteorologica IV as an authoritative text that explained how to identify homeomers by their passive features..$^{10}$ In the sixteenth and seventeenth centuries proponents of alchemy, such as Joachim Jungius and Daniel Sennert, again based a corpuscular alchemy on their readings of Meteorologica IV. They also used this book as support for arguments that maintained a relative equivalence between art and nature, a crucial point for those who wished to maintain that true gold could be manufactured artificially. ${ }^{11}$ While it is clear that alchemists utilised Aristotelian texts, we know little about how interpreters of these texts utilised alchemy. Commentaries on Aristotle's texts, most always written by university professors, were one of the primary means of expressing and spreading views on natural philosophy from the twelfth century until the end of the seventeenth. ${ }^{12}$ The importance and vitality of the Aristotelian commentary tradition to developments in natural philosophy is well documented..$^{13}$ An examination of the commentary tradition shows that by the beginning in the Middle Ages commentators frequently were aware of the relevance of alchemy to Meteorologica IV and vice versa. This awareness continued throughout the Early Modern period. In particular, a number of Renaissance commentators explicitly stated that this book was useful for alchemists and other kinds of metal workers.

9 William R. Newman, The Summa Perfectionis of Pseudo-Geber (Leiden: E. J. Brill, 1991), 171-190.

${ }_{10}$ Barbara Obrist, "Die Alchemie in der mittelalterlichen Gesellschaft," in Die Alchimie in der europäischen Kultur- und Wissenschaftgeschichte, ed. Christoph Meinel (Wiesbaden: O. Harrassowitz, 1986), 33-59; Barbara Obrist, The Book of the Secrets of Alchemy (Leiden: E. J. Brill, 1990), 65; Aristoteles chemicus: Il IV libro dei Meteorologica nella tradizione antica e medievale, ed. Cristina Viano (Accademia Verlag: Sank Augustin, 2002).

${ }^{11}$ William R. Newman, "Corpuscular Alchemy and the Tradition of Aristotle's Meteorology, with Special Reference to Daniel Sennert," International Studies in the Philosophy of Science 15 (2001): $145-153$.

${ }^{12}$ Charles H. Lohr, Aristotle Renaissance Commentaries II. Renaissance Authors (Florence: Olschki, 1988); Charles H. Lohr, "Medieval Latin Aristotle Commentaries," Traditio 23 (1967): 313-413 (Authors A-F); ibid. 24 (1968): 149-245 (Authors G-I); ibid. 26 (1970): 135-216 (Authors Jacobus-Johannes Juff); ibid. 27 (1971): 251-351 (Authors Johannes de Kanthi-Myngodus); ibid. 28 (1972): 281-396 (Authors Narcissus-Richardus); ibid. 29 (1973): 93-197 (Authors Robertus-Wilgelmus); ibid. 30 (1974): 119-144 (Supplementary Authors).

13 The essays in Aristotle Transformed: The Ancient Commentators and their Influence, ed. Richard Sorabji (London: Duckworth, 1999) illustrate the philosophical originality of the ancient commentary tradition. The intellectual vitality of the Renaissance commentary tradition is maintained in the follow works: Bruno Nardi, Saggi sull' Aristotelismo padovano dal secolo XIV al XVI (Florence: G. C. Sansoni, 1958); John H. Randall, The School of Padua (Padua: Antenore, 1961); Paul O. Kristeller, La tradizione aristotelica nel Rinascimento (Padua: Antenore, 1962); Antonino Poppi, Introduzione all'aristotelismo padovano (Padua: Antenore, 1970); Charles B. Schmitt, A Critical survey and bibliography of studies on Renaissance Aristotelianism, 1958-1969 (Padua: Antenore, 1971); Charles B. Schmitt, Aristotle and the Renaissance (Cambridge, Mass.: Harvard University Press, 1983); Charles B. Schmitt, "Towards a History of Renaissance Philosophy," in Aristotelismus und Renaissance, eds. Eckhard Kessler, Charles H. Lohr and Walter Sparn (Wiesbaden, 1988), 9-16; Christia Mercer, "The Vitality and Importance of Early Modern Aristotelianism," in The Rise of Modern Philosophy, ed. Tom Sorell (Oxford: Oxford University Press, 1993), 33-67. 
The awareness of the relevance of Meteorologica IV increased in its commentaries during the first years of the seventeenth century. One exceptional example, Niccolò Cabeo, used this work in order to proselytise alchemy as an ideal science that by properly utilising experimental procedures corrected what he understood to be the overly metaphysical and bookish interpretations of Aristotle frequently made by his colleagues. By giving an alchemical interpretation Cabeo strove to update Aristotelianism so that it could compete with contemporary novel natural philosophies.

\section{Meteorologica IV and Alchemy}

The field of alchemy did not exist until several centuries after Aristotle's death. Despite the fact that Aristotle did not specifically endorse a theory of transmutation of metals, his general theory of matter, and more precise views about the nature of metals influenced both alchemists and polemicists against alchemy. Even though Greek natural philosophy concerned itself with the formation of metals and their characteristics, ${ }^{14}$ the question of the transmutation of metals was not investigated at all in the centuries surrounding Aristotle's life. Nevertheless, Aristotle's theory of the formation of metals and his understanding of the material causation of inanimate homeomerous bodies in the Meteorologica potentially allows the artificial production of metals. ${ }^{15}$ While Aristotle did not discuss alchemy, his views on the natural and the artificial had import for alchemical theory. In Meteorologica IV, he defined the process of concoction, which accounts for changes in the matter of substances. Concoction occurs in both natural and artificial processes. It is defined as the mastery of the passive qualities by an intrinsic heat. The flexibility of this term is apparent from Aristotle's definitions of the subspecies of concoction: boiling and roasting, both artificial processes. ${ }^{16}$ Roasting is the mastery of passive qualities by an external dry heat; and boiling is caused by an external wet heat. The concept of concoction is extended towards any process whereby heat solidifies and defines passive material. Aristotle writes:

Roasting and boiling come to be by artifice, but, as we have said, there are natural processes which are identical to these with respect to form. For the passive qualities which arise from these processes are similar, although they do not have proper names. For art imitates nature. Thus, the digestion of food in the stomach is similar to boiling, for it occurs in a wet and dry place under the effects of bodily heat, and some kinds of indigestion are similar to scalding. ${ }^{17}$

In this passage, distinctions between artificial and natural processes are suppressed. Natural concoction is common to processes such as ripening, digestion and the generation of offspring. These natural forms of concoction have parallels in artificial processes, some of which are characterised as being metaphorically similar to natural processes, and others

${ }^{14}$ Robert Halleux, Le problème des métaux dans la science antique (Paris: Belles lettres, 1974).

15 For works that show how Aristotle's writings potentially support alchemical theories see Cristina Viano, "Aristote et l'alchimie grecque: La transmutation et le modèle aristotélicien entre théorie et pratique," Revue d'histoire des sciences 49 (1996): 189-213; Edmund O. von Lippmann, "Chemisches und Alchemisches aus Aristoteles," Archiv für die Geschichte der Naturwissenschaften und der Technik II (1910): 233-300.

${ }^{16}$ For the flexibility of the term concoction see G. E. R. Lloyd, Aristotelian Explorations (Cambridge: Cambridge University Press, 1989), 83-103.

17 381b3-9. 
identical with respect to form. ${ }^{18}$ For example, boiling, in a strict sense, does not occur in nature but only through the intervention of humans. Nevertheless, boiling is identical in form to animal digestion. Both processes result when an external wet heat masters passive matter. In the case of digestion, the heat within the stomach masters the passive food so that it is assimilated with the rest of the organism. Similarly, cooking uses external heat to master food so that liquid foods solidify and reach a state of maturity so that they can be consumed more easily.

The blurring of the artificial and natural in Meteorologica IV and the prominence of the phrase that "art imitates nature" 19 prompted discussions concerning alchemy in commentaries on this book. The possibility of the identity of art and nature was of particular interest to those who believed that it was possible to artificially create metals.$^{20}$ Conversely, those who maintained that artificial works could not attain the status of naturally created substances interpreted these passages so that art only imitated nature in a weak sense, imitated it without successfully copying it. For them, artificially created products remained mere imitations. ${ }^{21}$

While Aristotle's treatments of the natural and the artificial attracted a number of references to alchemy in commentaries on Meteorologica IV, several other passages were relevant to alchemical theories. In chapter six, there is a brief discussion of how crude iron is transformed into steel ${ }^{22}$ the eighth chapter describes metals as being composed of water, earth and the exhalations; ${ }^{23}$ and there are occasional references to metals through the final chapters that discuss the passive properties and the ratios of elements that compose them. ${ }^{24}$ In particular, Aristotle's contention that metals are composed out of earth and water provoked comments because it contradicted prominent alchemical theories that held that sulfur and mercury were the material constituents of metals. Moreover, Aristotle's claim that mercury is incapable of solidification was compared with the results found in alchemical writings. ${ }^{25}$

\section{Medieval Commentaries}

Medieval works had a significant impact on Renaissance commentators. Works attributed to Thomas Aquinas, Albertus Magnus and Avicenna greatly influenced how later commentators approached alchemy and its relation to Meteorologica IV. This book became linked with alchemy in the Latin West in large part as a result of a textual error in the twelfth century when a portion of Avicenna's Kitab al-shifa, which received the Latin name De mineralibus in Alfred of Sareshel's translation, was appended to Meteorologica IV. ${ }^{26}$ The identification of the De mineralibus as Aristotelian had a significant impact on how

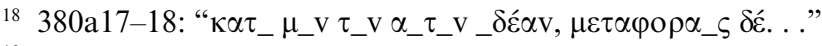

19 381b6-7; See also 379b14; 381a10.

${ }^{20}$ Such as Daniel Sennert, for example. Newman, "Corpuscular Alchemy and the Tradition of Aristotle's Meteorology.'

${ }^{21}$ Such as Cremonini, see below.

22 383a33-383b5.

23 384b32-35.

${ }^{24}$ E.g., 385a33; 385b13-14; 386a17-22; 387b25-28; 388a14; 389a7; 390a17; 390b11.

25 385b1-5.

${ }^{26}$ F. H. Fobes, "Mediaeval versions of Aristotle's Meteorology," Harvard Studies in Classical Philology 10 (1915): 297-314; Lorenzo Minio-Paluello, "Henri Aristippe, Guillaume de Moerbeke et les traductions latines médiévales de 'Météorologiques' et du 'De Generatione' d'Aristote," in Opuscula (Amsterdam: Hakkert, 1972), 57-86. 
medieval natural philosophers conceived alchemy as well as Aristotle's views of it. Avicenna's work used Aristotelian principles to explain the formation of stones: stones are formed in two different ways - either from conglutinatio, or hardening, of clay in which earth predominates, or through the congelatio of water. In either case, the formation of stones takes place in the presence of the appropriate water in the ground where there are petrifying, mineralising or solidifying virtues. ${ }^{27}$

In the De mineralibus, minerals are of four different species: stones, fusible (liquefactiva) substances, sulfur and salt. The discussion of these four species has many resemblances to Meteorologica IV. Avicenna considered the relation between the passive qualities of ductility and the ability to be melted, as well as the relation between ratios of elements and passive qualities; his terminology and arguments strongly resonate with Meteorologica IV.8-10. While his knowledge of minerals and the categorisation of them into four species was likely dependent on contemporary alchemical theory, his explanation of the differences of these species remained based on his knowledge of the four Aristotelian elements and prime qualities.

The De mineralibus also contains Avicenna's dismissal of the possibility of the transmutation of metals. The final section of the De mineralibus, which was often identified by its incipt: "Sciant artifices," argued that alchemists cannot change metals from one species to another. Avicenna's contention is based on two principles: (1) Art is weaker (debilior) than nature, and its products can only be similar to natural products and never be equivalent to natural kinds; (2) it is only possible to change the accidental and sensible qualities of metals, not their substantial forms. Thus, the fixity of the species, according to Avicenna, applies not only to plants and animals, but minerals as well. Regardless of the merits of Avicenna's views, their accuracy as interpretations of Aristotle is questionable. While Aristotle argued that art imitates nature, and art itself cannot create organisms or organic matter, it is possible that homeomerous substances can arise through artificial means and that on levels of matter close to the elements the distinction between artificial and natural processes is less clear. Furthermore, while Aristotle believed that species of plants and animals are eternal and cannot be transmuted, that is not his view for all homeomerous substances. For example, the elements transmute into each other, and concoction is a description of the transformation of homeomerous substances. Nowhere did Aristotle explicitly argue that the species of metals is fixed.

In general, medieval commentators somewhat contradictorily accepted both Avicenna's views and the claims of alchemists, even after the 1260s when it became widely accepted that the De mineralibus was not a genuine work of Aristotle. ${ }^{28}$ Albertus Magnus ${ }^{29}$ (ca. 1200-1280)

27 Avicenna, De congelatione et conglutinatione lapidum, eds. E. J. Holymyard and D. C. Mandeville (Paris: Paul Geuthner, 1927), 46-7.

28 The widespread opinion that Aristotle did not write the De mineralibus coincided with the diffusion of William of Moerbeke's translatio nova. For example Roger Bacon (ca. 1219-ca. 1292) refers to this work as authentic until sometime in the 1260s. See Opera hactenus inedita Rogeri Baconi. Fasc. IX, eds. A. G. Little and E. Withington (Oxford, 1928), 159: "Liber de corporibus inanimatis totaliter deficit, quia pauca capitula, que addita sunt in fine Metheororum, non sunt de textu Aristotelis, sicut ex alia translatione notum est." William R. Newman notes that by the 1260 s Bacon considered the De mineralibus to be in the domain of fools: Newman, The Summa Perfectionis, 20-25. E. J. Holmyard and D. C. Mandeville identify the date of Bacon's reversal as 1266: De congelatione et conglutinatione lapidum (Paris, 1927), 10.

29 On Albertus Magnus' knowledge of alchemy see Pearl Kibre, "Albertus Magnus on Alchemy," in Albertus Magnus and the Sciences, ed. James A. Weisheipl (Toronto: Pontifical Institute of Mediaeval Studies, 1980), 187-202. 
accepted the results of alchemical practice that contradicted Aristotle's claim that mercury (hydrageros or argentum vivum) is incoagulable, arguing, that, while it is not easy, with the proper mixture of earth, mercury does in fact dry out. According to Albertus, alchemists coagulate mercury by mixing sulfur with it at a high temperature.$^{30} \mathrm{He}$ pointed out that this is not a true instance of coagulation because the process is not reversible; the solidified mercury cannot be reduced to liquid again. Therefore, he concluded, that this process represents a modification of species rather than a modification of accidental qualities. ${ }^{31}$ This theory assimilated both Avicenna's view that minerals are composed out of sulfur and mercury, while simultaneously accepting the possibility of the transformation of mercury into a solid, possibly cinnabar.

The commentary of [Ps.-] Thomas Aquinas ${ }^{32}$ shows a similar ambivalence towards Avicenna's views. He concurred that the material components of metals are mercury and sulfur and that metals differ with respect to species, but nevertheless maintained the possibility that metals can be transformed. Arguing that Meteorologica IV is useful to alchemy, [Ps.-] Thomas contended that even though it was difficult, nevertheless it was possible to transmute metals. In his view, even though they differ by species, metals share the same nature and underlying matter: namely sulfur and mercury. Therefore he maintained that by applying the proper active forces, alchemists are capable of changing the nature of metals through congelation and conglutination. Meteorologica IV, in his opinion, was useful for understanding these processes because it teaches the relation between evaporation and the matter of metals..$^{33}$ Thus, while Avicenna's mercury-sulfur theory continued to be accepted, the immutability of the species of metals did not find acceptance.

${ }^{30}$ Albertus Magnus, Liber quartus Meteororum in Opera Omnia, vol. 4, ed. August Borgnet (Paris: L. Vivès, 1890), 773: "Magis tamen oleum est incoagulabile quam argentum vivum . . . sed argentum vivum propter multam commixtionem sui humidi cum terreo, non de facili constat et exsiccatur. . . In operibus autem alchimicis siccatur per multam adustionem et mixtionem sulphuris cum ipso non omnino adurentis ipsum." Peter of Auvergne (d. 1304) repeated more or less faithfully Albertus's view, see his: Expositio super quatuor libris metheorum Aristotelis (Salamanca, 1497) fol. [u ii recto]: "unde quamvis argentum vivum admixtione sulphuris non adurentis possit coagulari \& aliis pluribus modis. sicut docent alkimici. quia tamen hoc est mutatione speciei nihilominus est incoagulabile."

31 Albertus Magnus, Liber quartus Meteororum, 774: "Et ideo non est instantia quae inducta est de praedicto exemplo, quod coagulata quando solvuntur, et soluta quando coagulantur, in eadem specie manent, sicut aes coagulatum et liquidum in una specie: hydrageros autem praedicto modo constans non manet specie una, nec in eisdem componentis." He also discussed the transmutation of substances at 758: "Non enim negamus hoc quod dicunt Alchimici, scilicet quod de omni re trahatur oleum et nitrum et aurum per ignem proportionatum et successive et continue agentem acute vel lente, secundum quod exigit proportio rei transmutandae."

32 The actual author of this work has not been identified. See A. Dondaine and L. J. Bataillon, "Le commentaire de saint Thomas sur les Météores," Archivum Fratrum Praedicatorum XXXVI (1966), 81-152. No Renaissance commentator, however, questioned its attribution to Thomas.

33 [Ps.-] Thomas Aquinas, In libros Aristotelis Meteorologicorum expositio, ed. Raimundo M. Spiazzi (Rome: Marietti, 1952), 646: "Est insuper utilis ad scientiam alchimiae: quia tantummodo alchimistarum est transmtuare metalla secundum veritatem, et non secundum sophisticationem; quod licet sit difficile et dispendiosum, sicut supra dictum est, non tamen est impossibile. ... Sed credo quod differunt secundum speciem, et nihilominus transmutari possent adinvicem, quia sunt naturalia et materia eorum est una. Quod autem hoc fiat per artem est difficile, non impossibile. Non tamen intelligi debet quod artifices principaliter transmutent, sed agunt quasi instrumenta applicando propria agentia propriis passivis: quia materia propinqua omnium metallorum est 


\section{Alchemy in Renaissance Commentaries on Meteorologica IV}

The views of Albertus and [Ps-] Thomas provoked many of the comments on alchemical issues in Renaissance commentaries on Meteorologica IV, although discussions of alchemical topics found in later medieval commentaries, such as in Themo Judei's Quaestiones, were either unknown or ignored.$^{34}$ Renaissance commentators, however, did not share the general acceptance of the possibility of the transmutation of metals that prevailed among medieval scholars. Because the field of alchemy was developed centuries after Aristotle's death, assimilating his work to alchemy or vice versa was seen as anachronistic to interpreters influenced by humanism. ${ }^{35}$ Furthermore, a close reading of Aristotle's text, while not outright rejecting alchemy, nonetheless did not necessarily support it. The mercury-sulfur theory of metals, championed by alchemists, clearly did not correspond to Aristotle's text, which sustained that metals were formed out of earth, water and the exhalations trapped within the earth's surface.$^{36}$ For many Renaissance Aristotelians, influenced by humanism, the ideal of commenting was to identify the true intent of Aristotle. Literal interpretations of the text were typically favored. Thus, in the first part of the sixteenth century, commentators on Meteorologica IV rarely dealt with alchemical issues that depended on the mercurysulfur theory, a theory that clearly extended beyond a literal textual reading. When they did discuss alchemy, it was usually in response to Albertus Magnus's discussion on the ability of mercury to coagulate.

In his comments on Meteorologica III.6 written in 1523, in contrast to his medieval predecessors, Agostino Nifo (ca. 1469-1538) denied outright the possibility of the artificial production and transmutation of metals, claiming that Aristotle himself "reprimanded the fusitive art." In his opinion it was impossible to convert metals by concoction or distillation; metals could only be created by the heat of celestial powers in fixed places underneath the earth. ${ }^{37}$ Nifo's disdain for alchemy extends to the name itself. "Alchimia" is a term for the "vulgar," while he preferred "ars fusoria," a term that reflects the origins of the Arabic word

33 continued

argentum vivum et sulphur, sicut dictum est quorum naturas artifices transmutare possunt conglutinando et congelando. Vel etiam alio modo evaporatio est materia praedictorum: et de hac determinatur in isto libro, et ex consequenti iste liber et utilis ad scientiam alchimiae."

34 Themo Judei, Quaestiones super quatuor libros Meteororum compilate per doctissimum philosophii professorem Thimonem (Paris: J. Bade \& C. Resch, 1518), 258-9.

${ }^{35}$ For this view, see the unsympathetic attitudes toward alchemy in Sebastian Fox Morcillo, De naturae philosophia, seu de Platonis, et Aristotelis consensione (Louvain: P. Colonaues, 1554), 158: "Altera est Chymistarum, id est, huius aetatis insanorum hominum (neque enim antiquitus ulli tales fuere) qui duo metallorum omnium principia statuunt. .." This question, however, was apparently under debate, see Girolamo Trimarchi, Disputationes in libros Aristotelis Meteororum (Genoa: P. J. Calenzanus \& M. Farronus, 1637), 335: "Quaeres hic, An origo huius artis sit antiqua? Vetustissimam nonnulli esse dicunt, sed multi tradunt, non tantum incerta, sed etiam vera somnia: illud est verum, nihil in historiis de hac arte haberi ante tempora Caligulae. .."

36 378a26ff.

${ }^{37}$ Agostino Nifo, In libris Aristotelis Meteorologicis commentaria (Venice: G. Scoto, 1560), 122r: "Reprobat igitur hanc fusoriam artem Aristoteles..." Ibid., “...patet fusoriam artem, quam vulgares alchimiam dicunt, esse inutilem, \& impossibilem, ac damnosam. Non enim potest metallum fieri, nisi ex vapore non dum in aquam verso, \& a frigido naturali, quod sub terram est, \& potissimum intra lapides, \& quod est regulatum a virtute caelesti minerali, quae non est, nisi in locis sub terra convenientibus generationi metallorum.” 
in the Greek word $\chi \varepsilon_{-} v$, which means to melt or smelt. ${ }^{38}$ His use of a Latin neologism rather than a translation of an Arabic word reflect the tendency among Renaissance scholars to rid themselves of large portions of the Arabic medieval tradition, which was frequently considered to contain errors and barbarisms. The demands of the locus classicus, however, were such that when confronted with the line that describes mercury as incoagulable, he cited the views of alchemists as preserved in Peter of Auvergne's commentary. Elaborating on Albertus Magnus's and Peter of Auvergne's views, he sided with Aristotle's opinion that mercury does not coagulate, despite the experiments of alchemists that he appeared to know only from medieval commentaries, which are quoted word for word. Even though mercury solidifies when properly mixed with sulfur, according to Nifo, this transformation represents a change in species, and therefore mercury qua mercury is incoagulable. ${ }^{39}$ The cost of maintaining Aristotle's dictum that mercury does not solidify is the concession that it changes species, thereby undermining his earlier claims against the possibility of transmutation, although he allows a loophole by not conceding that the new species is a true mineral or metal.

Nifo's doubts about the possibility of transmutation of metals are restrained when compared to the scepticism of Lodovico Boccadiferro (1482-1545), a prominent professor at the University of Bologna. In his commentary on the Meteorologica he crossed the line from critiques of textual interpretation and philosophical coherency to attacks on character. ${ }^{40}$ After citing Albertus Magnus's discussion on the solidification of mercury, he distances himself from the medieval tradition by expressing his worries about the application of evidence taken from alchemical writers, whom he characterised as notorious liars who waste fortunes in their attempts to turn mercury into real silver. What is worse in his judgement was that they failed to believe Aristotle. ${ }^{41}$ As a result, the experiments of alchemists had little worth to Boccadiferro because they contradicted the Stagirite's words. Thus the needs of literal exegesis trumped experience.

Even though some Renaissance commentators on Meteorologica IV distinguished themselves from medieval positions and remained sceptical of the possibility of alchemical

${ }^{38}$ For the etymology of "alchimia" see William R. Newman and Lawrence M. Principe, "Alchemy vs. Chemistry: The Etymological Origins of a Historiographic Mistake," Early Science and Medicine 3 (1998): 38

39 Nifo, In libris Aristotelis Meteorologicis, 139v: "Sed contra haec dubitatio est, quoniam argentum vivum per admixtionem sulphuris non adurentis coagulari potest, $\&$ aliis pluribus modis, ut fusores dixerunt. Dicendum quod aliquod coagulari, esse potest bifariam, aut ipso remanente a principio ad finem in eadem speciem, \& hoc pacto argentum vivum coagulari potest, non tamen ipso remanente in eadem speciem, sed specie mutata ut fusores docent." The initial phrase of this doubt comes from Peter of Auvergne, see note 30.

${ }^{40}$ Both Nifo's and Boccadiferro's views influenced the Florentine courtier and academic Benedetto Varchi, who wrote a disputation on alchemy in 1544. See pp. 61 and 68 of the printed transcription of this work: Benedetto Varchi, Questione sull'alchimia (Florence: Magheri, 1827). See also Alfredo Perifano, "Benedetto Varchi: Une analyse de la Questione sull'alchimia," Chrysopoeia 1 (1987): 181-208. For a discussion of his relation to Boccadiferro see Umberto Pirotti, "Benedetto Varchi e l'aristotelismo del Rinascimento," Convivium 31 n.s. (1963): 280-311.

${ }^{41}$ Lodovico Boccadiferro, Lectiones in librum IV Meteororum (Venice: F. De Franceschi, 1563), 203 : "Sed domini, ego non credo istis chymicis, quia multa mendacia proferunt, \& multum laborant in hac congelatione, quae valde difficilis est: $\&$ multi consumpsere patrimonia, quaerentes id, quod non habent perdendo quae habent; $\&$ non credunt Aristoteli, quod dicit hic, quod argentum vivum non potest congelari." 
transmutations, by the middle of the century, commentators increasingly noted the utility of this book for alchemy, although far less frequently than they did for medicine. ${ }^{42}$ Francesco Vimercati (1512-1571), a Milanese professor of classical languages at Paris, claimed that this book was useful to alchemy. His infrequent references to alchemical theory or practice, however, suggest that he had little experience with this field beyond what he learned from Albertus Magnus's commentary, although his use of the term "ars fusoria" hints to his desire to update the name of the alchemy so it reflected humanist Latin usage. ${ }^{43}$ Ascanio Conti, a Venetian evidently trained at the University of Padua, described Meteorologica IV as particularly useful for alchemy, as he frequently considered practical utility in his introduction to natural philosophy. ${ }^{44}$ More thorough was Francesco Piccolomini (1523-1607), a prominent professor of natural and moral philosophy at Padua, who argued that in addition to being useful to medicine this book was useful to alchemy because it revealed which principles of alchemy are valid and which are not. Furthermore, in his somewhat idiosyncratic view among commentators on Meteorologica IV, the book's utility extended to natural magic which he understood to be the manipulation of active and passive elements of nature. ${ }^{45}$

For Piccolomini, medicine, alchemy and natural magic were based on common principles. He went so far as to claim that "medicine is natural magic." 46 In response to Aristotle's claim that boiling, whether natural or artificial, is of the same species, he argued that while artificial and natural examples of this process differed with respect to instrumental causes, they were identical with respect to their efficient cause, namely heat, and with respect to the passive matter. Citing the seventh book of the Metaphysics, he maintained that these crafts do not utilise artificial heat, but rather harness natural heat; the efficient cause remains natural, but physicians, alchemists and magicians become instruments, applying natural heat onto appropriate passive substrates. ${ }^{47}$

${ }^{42}$ For connections between Meteorlogica IV and medicine in the Renaissance see Craig Martin, "Francisco Vallés and the Renaissance Reinterpretation of Aristotle's Meteorologica IV as a Medical Text," Early Science and Medicine 7 (2002): 1-30.

${ }^{43}$ Francesco Vimercati, Commentarii in IV libros Meteorologicorum (Paris: D. Guerra \& G. B. Guerra, 1565), 191 ${ }^{\mathrm{r}}, 199^{\mathrm{r}}, 216^{\mathrm{v}}$.

44 Ascanio Conti, Praefationes sex in omnes Aristotelis libros philosophiae naturalis (Venice: G. Perchacinus, 1570), 77r: "Perdiscet etiam corpus densius rarefacere, $\&$ rarius contringere. Fundendi quoque ars, conflandique metalla maximam ab hac facultate sumit utilitatem, hic enim metallorum materia, \& eorum modus productionis, quaeque sit illorum cuiusque natura, quae arti fusoriae pernecessaria sunt, explicatur."

45 Francesco Piccolomini, Lectiones in quartum Meteorologicorum, Ms. Biblioteca Ambrosiana D 409 inf., fol. $1^{\text {r: }}$ "Adeoque si medicina sumat principia sua a naturali philosophia, praesertim ex hoc libro verificatur, insuper chimicae arti operam tradit, quam addiscere debetis, ut principitatis quid boni, quod veri, in ea sit, non ut operas nostras in summum resolvatis. Confert etiam magiae naturali quae consistit in recta applicatione agentium, patientium naturalium quorum quidam naturalium virtutes. .."

${ }^{46}$ Piccolomini, Lectiones, fol. 157r: "Sic medicina est magia naturalis."

${ }^{47}$ Piccolomini, Lectiones, fols. 157 $7^{\mathrm{r}}-157^{\mathrm{v}}$ : "Idem est agens, materia eadem est, ergo et effectus idem. Quod probatur quia a quocumque fiat concoctio vel a natura vel ab arte fiat, semper dicendum concoctiones fieri a natura quia debemus considerare agens principium, non est considerandum instrumentum se consideremus principium agens est natura [vel] est aliquod naturale, ideo cochus [i.e. coquus] quamvis videatur concoquere carnem, vel assare, hoc facit ipsa natura, coquus est instrumentum, est magus naturalis, quia applicat agentia naturalia, sic medicina est magia 
As a result Piccolomini believed that artificial products did not intrinsically differ from artificial ones. Accordingly, he maintained that alchemists can generate metals. In his eyes, however, art remained weaker than nature and the human production of gold was impossible because it required active forces that were too strong. ${ }^{48}$ Furthermore, he reconciled Aristotle's ideas with the sulfur-mercury theory of metals in his outline of the material causes of the production of metals. According to his interpretation of Aristotle, the generation of a substance requires the hot to act on a wet passive material. Piccolomini identified the hot as sulfur, or in metaphorical terms the father, and the wet as mercury, or the mother. ${ }^{49}$

Piccolomini's defense of alchemy was rare among Paduan commentators of Meteorologica IV. Scepticism toward this field often prevailed. For example his successor, Cesare Cremonini (1550-1631), the infamous adversary and colleague of Galileo Galilei, writing against those who "accept the arguments of the Alchemists that it is possible that the identical gold is made by nature as is by art," argued against the posibility of artificial production of metals. To the contrary, Cremonini believed that just as offspring can only be created in their parents, metals required a determinate place underneath the earth. Therefore, he argued that art cannot do everything that nature could do; artificial metals are as possible as artificial humans..$^{50}$

While in Paduan circles, alchemy received little attention, an increased concern for the alchemy in commentaries on Meteorologica IV arose with the Jesuit commentary produced at the University of Coimbra. The orientation of this book around the elements rather than the text, meant that the fourth and final book of this commentary was dedicated to the affections of the earth. Thus the final three treatises of this work discuss earthquakes,

${ }^{47}$ continued

naturalis, quia medicus cognoscens naturam auxiliarum, et morbi applicat agentia patientibus sic medicus dicitur instrumentam naturae, sic Aristoteles septimo [libro] metaphysicarum dicebat eadem sanitas ab arte, et a natura fieri potest, quomodo quia quamvis ars curet, curare potest ut agens instrumentarium ut instrumentum. Concurrit ars quare solvens difficultatem. Dico concoctio fit $\mathrm{ab}$ arte, et a natura, istae concoctiones vel considerantur ea ratione qua una est ab arte alia a natura, vel consideratur absolute sub hac ratione quatenus una est ab arte, alia a natura distinguitur, sunt diversae species, sed si considerentur hoc modo quo ad instrumenta, per quae non distinguitur intrinsece et essentiali rei species, sed distinguitur extrinsece, et accidentaliter, si consideretur concotio ab arte, et a natura intrinsece, quod praecipuum efficiens, quoad formam dicimus quod semper sunt eiusdem speciei, quia semper causa efficientes est natura." Cf. Metaphysics, 1032b5-14.

${ }^{48}$ Piccolomini, Lectiones, fols. $157^{\mathrm{v}}-8^{\mathrm{r}}$ : "Sed evenit quod aliquando agentia patientibus possunt applicari pro generatione quorundam metallorum, sed quaedam sunt metalla, ut aurum non potest. Homo per artem chimicam agentia applicare patientibus pro generatione auri, quia concurrit valentius agens,..."

49 Piccolomini, Lectiones, fol. 28v: "consideremus quomodo metalla generantur. Quia dicuntur habere patrem, et matrem. Pater est causa efficiens, mater dicitur esse materia. Pater est sulphur aliquid calidum, et siccum, mater dictum esse argentum vivum, pater ergo dicitur esse sulphur quia per eius caliditatem fiunt metalla, cum pater metallorum sit aliquid maxime calidum, ut sulphur, ideo a praedominio calida esse dicuntur." Other references to the generation and corruption of metals are found in fols. $37^{\mathrm{v}}-8^{\mathrm{r}}, 46^{\mathrm{r}}$.

${ }^{50}$ Cesare Cremonini, In quartum librum Aristotelis Meteorologicorum, Ms. Padova (Biblioteca Universitaria, 1210), 711-12: "generatio hominis requirit determinatum locum in utero mulieris; quia iste locus determinatus requiritur. Non potest facere Ars, id quod natura sine tali determinato loco, quem etiam locum aliquando Ars nec potest parare ut in hominis generatione." 
subterranean fires and metals, topics more closely linked to Meteorologica III than the following book. Even though the University of Coimbra's commentary had little to say about alchemy per se this was not true for some who followed its form and style. ${ }^{51}$

The final book of the Franciscan Girolamo Trimarchi's Disputationes in libros Aristotelis Meteororum (1637) is dedicated primarily to a discussion of alchemy, or what he calls "ars chemica," or "archimia." Although he considered the subject of Meteorologica IV to be perfect homeomerous mixtures, he justified his decision to address minerals, which he assimilated to the subject of ars chimica, by claiming that there are more suitable books of Aristotle, presumably those of De generatione et corruptione, for discussing perfect mixtures, the actual subject of Meteorologica IV.

While Trimarchi's stated position is plausible, it seems more likely that he was following the organisation of the University of Coimbra's commentary, as he did for the earlier books. He, however, supplemented these topics with disputations on the merits of alchemy and more detailed considerations of the metals. He was not alone in following the University of Coimbra's commentary's arrangement; John of Saint Thomas also arranged his commentary on the Meteorologica in his Cursus Philosophicus Thomisticus (1634) so that it followed closely the questions and arguments of the Jesuit work. As a result, the final portions of his work are dedicated to the nature of metals. His discussion of the text is informed only by a few sources: Thomas, the Church Fathers, the Bible and Aristotle. Thus, in his discussion of metals he considered alchemical thought as it appears in these sources. Having cited [Ps.-] Thomas's commentary, he argued in favour of the view of alchemists that the proximate matter of metals is composed of sulfur and mercury. ${ }^{52}$ The discussion of alchemy by these members of religious orders does not appear to be motivated by spiritual aims; for them alchemy is not a metaphor for spiritual cleansing. Rather, their treatments combine the alchemical concerns of Albertus and [Ps] Thomas with the mineralogical concerns of the University of Coimbra's commentary on the Meteorologica.

In contrast to John's work, Trimarchi's Disputationes is a rich discussion of the status of alchemy in scholarly writings. While self-consciously avoiding a treatment of the contents of Meteorologica IV, it addressed the need of treating alchemy in a course on Aristotelian natural philosophy. Starting from the premise that "art imitates nature," Trimarchi was convinced of the possibility of the artificial creation and transmutation of metals. The powers of craft, in his eyes, were not limited to the production of gold, but could also generate animate beings, namely bees, crabs and scorpions. ${ }^{53} \mathrm{He}$ supported these views by a wide

${ }^{51}$ It mentioned the views of alchemists who held the sulfur-mercury theory of metals, however, it did not discuss the possibility of transmutation or artificial production. See Collegium Conimbricense, In quatuor libros de Coelo, Meteorologicos, \& Parva Naturalia, Aristotelis Stagiritae (Venice: A. Baba, 1606), 175-6.

52 John of Saint Thomas, Tractatus de Meteoris. Ad quatuor libros Meteorologicorum Aristotelis in Cursus Philosophus Thomisticus: Naturalis philosophia, pars III: De ente mobili corruptili, ed. P. Beatus Reiser (Torino: Marietti, 1950), 887: "D. Thomas lectio 9 in 3. Meteorologica utrumque conciliat dicens, quod materia remota metalli est illa exhaltio vaporosa, sed proxime est sulphur et argentum vivum, ut dicunt chimici, eo quod ipsi alchmistae faciunt aliquando ex ista materia metallum."

53 Trimarchi, Disputationes, 333: "Docent Philosophi, \& bene, quod opera naturae ars emulatur, verum illa, quam Alchimiam vocant communiter Auctores, potissimam sibi de natura palmam parat; \& ideo forsitan dicitur ars artium, \& ars sacra. . ."; 339: "Tum quia cum ars naturae imitrix sit, non apparet ulla ratio, cur illam imitari nequeat in efformando vero auro, . . . certissimum enim est quaedam animalia generari industria artis, ut apes Scarabei, \& crabones ex cadaveribus, \& ex stercore animalium; imo \& scorpiones ex herba Basilico rite posita, \& collocata certis locis.” 
range of citations that included traditional Aristotelian sources such as Albertus Magnus, the works ascribed to Thomas, the University of Coimbra's commentaries and Francisco Vallés's De sacra philosophia, as well as more recent authorities on alchemy, mineralogy and natural magic such as Paracelsus, Jean Fernel, George Agricola and Martin Del Rio.

Trimarchi divided alchemy into three separate varieties - one that resolves substances into their quintessences, another that purifies metals, and a third that transmutes metals, which is also known as chrysopoeia. ${ }^{54}$ The inclusion of disputations on this field, in particular the third part, in a work that treats Aristotelian science, is justified by the fact that alchemy, despite being a craft, is not a mechanical one, but rather a part of philosophy.$^{55}$ Thus, once the status of alchemy as a valid part of science has been established, Trimarchi proceeded by determining the qualities of metals in general, before a discussion of the properties of particular species of metals.

His dedication to alchemy, however, appears somewhat half-hearted, confined to knowledge taken from authorities and devoid of personal laboratory work. Furthermore because he believed that the formative cause of metals is celestial, he conceded that artificially producing gold is problematic.

\section{Cabeo's Commentary and Alchemy}

While Trimarchi used Meteorologica IV to launch a presentation of alchemy in Aristotelian terms apart from a reading of the book, his contemporary Niccolò Cabeo integrated alchemical teachings to expand and update his interpretations of the book. According to Cabeo, the methods and results of alchemy filled the experiential gaps in textual exegesis, thereby allowing him to adapt Aristotelian teaching so that it conformed to experience and could compete better with new natural philosophies. Unlike, Trimarchi, whose understanding of alchemy appears almost entirely bookish, Cabeo presented himself as a practitioner of alchemy, and argued that its methods of scrutinising beneath the outward layers of matter provided a more precise knowledge of nature than metaphysical speculation.

Born in Ferrara in 1582, Cabeo entered the Society of Jesus in 1602. He taught philosophy and mathematics at Parma (1608-1621) and then later at Ferrara, and finally Genoa where he lived until his death in $1650 .{ }^{56} \mathrm{He}$ is most famous for his role in interpreting a series of experiments conducted by Giovanni Battista Bailiani that appeared to demonstrate that falling objects of different weights fall a roughly the same rate..$^{57}$ His intellectual output is preserved in two printed works: Philosophia magnetica (1629), and his Commentaria in quatuor libros Meteorologicorum (1646).

54 Trimarchi, Disputationes, 334-5.

55 Trimarchi, Disputationes, 341: "Nota tandem, quod Chrisopeia, si vera est, non est ars mechanica, sed pars philosophiae non ignobilis."

${ }^{56}$ Ugo Baldini, "La scuola scientifica della provincia dal 1606 al 1660," in Legem impone subactis (Rome: Bulzoni, 1992), 427-436; Ugo Baldini, "I Gesuiti nelle corti padane (1600-1650)," in Saggi sulla cultura della Compagnia di Gesù (secoli XVI-XVIII) (Padova: CLEUP, 2000), 171-211; Lohr, Latin Aristotle Commentaries, 69-70; C. Sommervogel, Bibliothèque de la Compagnie de Jésus, vol. 2 (Brussels: Boulanger-Desideri, 1891), 483.

57 Serge Moscovici, L'expérience du mouvement: Jean Baptiste Baliani disciple et critique de Galilée (Paris: Hermann, 1967), 41-56; Attilio Frajese, "Niccolo Cabeo," in DSB, vol. 3 (New York: Scribner, 1971), 3 . 
In the Philosophia magnetica, Cabeo endorsed Aristotelianism, although it is far removed from the bookish natural philosophy one might expect to find in someone who wrote commentaries. Rather, Cabeo integrated a wide range of experiments in order to put forth his own interpretation of magnetic phenomena that is, in his opinion, acceptable to all Peripatetics. ${ }^{58} \mathrm{He}$ stressed that Aristotelian science is more than just logical deductions, and that Aristotle recognised diverse means for uncovering the truth. ${ }^{59}$ While open to mathematical explanation, Cabeo maintained that all of nature cannot be reduced to mathematical forms,${ }^{60}$ and as a result favoured explanations that were experimental and experiential. These explanations include those taken from the works of alchemists ${ }^{61}$ and a number of contrived tests on magnets, although he cautions that these experiments (experimenta) could be the path to both truth and error. ${ }^{62}$

In his massive Commentaria in quatuor libros Meteorologicorum Cabeo continued his preoccupations with method, experience and alchemy. Writing only a commentary on the Meteorologica, he defied the trend noted by Charles Lohr that beginning in the last part of the sixteenth century commentaries, especially those of noted Jesuits such as Francisco Toledo, Pedro da Fonseca and Francisco Suárez, increasingly treated metaphysics at the expense of natural philosophy. ${ }^{63}$ Nor was Cabeo interested in the Meteorologica because of its relation to medical topics, as were numerous professors in Spain and Italy. Rather, Cabeo's interest in this work was a remedy to these trends. Dismayed by the increased

${ }^{58}$ For example when examining Gilbert's view on the role of humidity in uniting metals he notes that it "consents to the peripatetic doctrine" and says that he "does not find it repugnant, nor should any Peripatetic (non repugnarem, nec repugnaret ullus Peripateticus)". See Niccolò Cabeo, Philosophia magnetica (Ferrara: F. Succius, 1629), 84. For seventeenth-century response to this work see: Ugo Baldini, "Uniformitas et soliditas doctrinae. Le censure librorum e opinionum," in Legem impone subactis (Rome: Bulzoni, 1992), 95-8.

59 Cabeo, Philosophia magnetica, 37: "sunt enim diversa hominum ingenia, \&, ut ait Aristoteles, aliqui volunt omnia mathematice demonstrari, aliqui dignum ducunt, si testis aliqus Poeta producatur.Verum ex eodem etiam didici istorum non maximam habendam esse rationem; cum sint ipso iudice indisciplinati ingenii, \& scientiam quaerant ante modum sciendi, hoc est ante modum procedendi illius scientiae: illud enim intelligit Aristoteles per modum sciendi, non Logicam, ut aliqui opinantur."

${ }^{60}$ Cabeo, Philosophia magnetica, 211: "Non possum hoc dictum ad Mathematicam redigere formam, tum quia physicum totum hoc est negotioum."

${ }^{61}$ Cabeo, Philosophia magnetica, 205: "is enim reverteretur ad Chymicorum ingenium, qui quoties vera loquuntur, \& quibus fidem experimenta concilient."

${ }_{62}$ Peter Dear, Discipline \& Experience: The Mathematical Way in the Scientific Revolution (Chicago: Chicago University Press, 1995), 64-7; Cabeo, Philosophia magnetica, 320: "Verum vel ex hoc intelligat lector, quam operosum sit bonis experimentis viam sibi ad rerum notitiam assequendam aperire; \& quam coniunctae sint in experimentis, hoc est initiis philosophiae veritatis, \& erroris viae."

${ }^{63}$ Charles H. Lohr, "The sixteenth-century transformation of the Aristotelian division of the speculative sciences," in The Shapes of Knowledge from the Renaissance to the Enlightenment, eds. Donald R. Kelley and Richard H. Popkin (Dordrecht: Kluwer, 1991), 49-60. Ugo Baldini notes that before Cabeo, Jesuits did not explore the field of meteorology in any depth. See "Legem impone subactis. Teologia, filosofia e scienze matemathiche nella didattica e nella dottrina della Compagnia di Gesù," in Legem Impone Subactis, 41. For a brief discussion of Cabeo's theory of matter and form in this work, see: Ugo Baldini, "L'evoluzione della 'fisica' dei gesuiti in Italia, 1550-1700: Un approccio strutturale," in Saggi sulla cultura della Compagnia di Gesù (secoli XVI-XVIII), 275-7. 
attention to metaphysical issues at the expense of natural philosophy among his contemporaries, he strove to create a "scientific" (scientificus) interpretation of Aristotle based on the interweaving of textual interpretation and experimental philosophy.

In order to fulfill this goal, Cabeo's divided his work according to the dual nature of his method. The comments were intended to reveal accurately Aristotle's meaning, while the Quaestiones aimed to go beyond what Aristotle believed and search out the truth unfettered by the demands of ancient authority. He contrasted the goals of the commentator with those striving for philosophical or scientific truth:

When in the explication of a text, it should not be judged, whether this or that was said correctly or incorrectly. I have said elsewhere that this is not the duty of the translator or the commentator. For the commentator ought only to explicate clearly what is said, if it should be less than clear, and to put forth the reasons, if they are asserted more clearly: not however to judge whether it is true or false. Nor is it proper to confirm or reject this opinion, but only to expound it. Here, therefore, it is proper, after the explication of the text to judge what was said. . .64

As a result Cabeo assumed a dual identity; in his comments he gave what he saw as pure explication, the literality prised by those influenced by humanism, and in the questions reserved the freedom to develop his own truths and thereby develop Aristotelian natural philosophy.

Philosophical truths, according to Cabeo, should be independent from attempts to preserve the authority of Aristotle. He cited Pomponazzi's claims that those who believe that Aristotle was infallible are stupid and that if Aristotle is wrong he should be condemned, ${ }^{65}$ and offered his judgment against those who practice philosophy using only the tools of "reading (lectio), commentary (commentatio), or speculation (speculatio)." ${ }_{66}$ Cabeo envisioned the good philosopher as capable of surpassing Aristotle's understanding of nature by utilising experience and experiments. He wrote: "Nor will the Philosopher ever become a scientific physicist (physicus scientificus) only by reading books of philosophy, unless he considers nature, and takes up experiments." ${ }^{97}$ Indeed, he believed that other unidentified

${ }^{64}$ Niccolò Cabeo, In libros Meteorologicorum Aristotelis commentaria, et quaestiones tomi quattuor, vol. 4 (Rome: F. Corbellettus, 1646), 334: "Cum in explicatione textus, non iudicem examinandum, quae sint recte dicta, quae non; hoc enim ut dixi alias, non est interpretis, seu commentatoris munus. Commentator enim debet solum clare explicare, quod dicitur; si minus clarum sit. \& rationes, si afferuntur enucleatius proponere: non autem expendere, utrum verum sit, an falsum. nec debet, aut confirmare aut confutare illam opinionem, sed solum exponere. Hic ergo placuit post explicationem textus expendere quae dicuntur. ."

${ }^{65}$ Cabeo, In libros Meteorologicorum, vol. 4, 302: "Quae dicuntur ab Aristotele hic, \& in sequentibus, videntur mihi dicta valde ad sensum vulgi, \& videntur egregie quadrare, quae dicuntur a Pomponacio: qui Philosophus est valde peripateticus, \& peripateticis addictissimus: Si quis putat omnia, quae dicuntur ab Aristotele philosophica, \& ad puram philosophiam spectantia, vera esse prorsus, \& indubitata, hic stultissimus est." Ibid., vol. 4, 427: "ut dicit Pompanacius si non est verum, suum damnum." This passage differs in wording but not in meaning from: Pietro Pomponazzi Dubitationes in quartum Meteorologicorum (Venice: F. De Francschi, 1563), 40v: "Multi volunt Aristotelem in omnibus bene dixisse, \& stulti sunt."

${ }^{66}$ Cabeo, In libros Meteorologicorum, vol. 4, 334: "Miror sane Philosophos nostros existimare se posse fieri perfectos, sola lectione, \& commentatione, seu speculatione. .."

${ }^{67}$ Cabeo, In libros Meteorologicorum, vol. 4, 353: "nec Philosophus erit unquam physicus scientificus, solum legendo libros philosophorum, nisi ipsam naturam consideret, \& experimenta sumat."; vol. 4, 306: "Sed ut videas, quam sit fallax philosophari per communia, \& velle naturas rerum indagate, non ex ipsis rebus; sed ex subtili commentatione.”; See also vol. 4, 305. 
commentators had been led astray by trying to solve Aristotle's obscurities without personally experiencing nature and thus had adopted a faith (fides) in Aristotelianism rather than a science (scientia) based on observation. ${ }^{68}$ With respect to the subject matter of Meteorologica IV, Cabeo primarily had in mind alchemical experiments, believing these experiments corrected both commentators of Aristotle, who were consumed only by reading, and Aristotle himself. According to Cabeo, Aristotle was "more accustomed to metaphysical speculation, than physical observation." ${ }^{69}$

Cabeo's concern over the excessively metaphysical occupations of Aristotle perhaps explains why he chose to write his only Aristotelian commentary on the books of the Meteorologica. The Meteorologica contains fewer discussions of metaphysical points than many of Aristotle's works on natural philosophy, and its central topic is material change and its causes, a subject that is more conducive to the application of observation and experiment than many of the libri naturales. Thus, Cabeo commented on this work in order to correct the trend of other Aristotelians who were moving away from physical understandings of nature and as a result ignored direct considerations of nature. He disdainfully observed that: "many Peripatetics occupied in these metaphysical subtleties do not read these books [i.e., the Meteorologica]." ${ }^{70}$ He pitted the scientific physicist against the metaphysician, who by his disregard of both nature and the physical parts of the Aristotelian corpus diminishes the strength of Aristotelianism by making it unable to compete against the novel natural philosophies that utilise observations of nature.

Alchemical research was particularly important to Cabeo because of its development of sophisticated techniques of experiment. ${ }^{71}$ According to Cabeo, alchemists were the true natural philosophers because they understand the principles of nature and the constituents of nature by breaking down the components of physical bodies. ${ }^{72}$ In his view, the laboratory research of alchemists surpassed the empirical knowledge of Aristotle, and thus offered an alternative to his doctrines. For example, he pointed out that crude metal melts, not when in contact with water but with strong corrosive liquids (i.e. acids), and thereby adjusted

${ }^{68}$ Cabeo, In libros Meteorologicorum, vol. 4, 334: "Cum tamen tota physica observationibus innitatur. quod si dicas, re observationes ab aliis sumere, $\&$ illis experientias relinquere: scito, te illis etiam scientiam relinquere, tibi fidem assumere. nec enim unquam philosophiam habebis physicam, absque experimentis. Multa ergo dicit hic Aristoteles, \& ex illo sequaces describunt, quae obscura sunt, \& difficultatem habent, \& quia interpretes noluerunt experiri, ne fortasse arguerentur falsitatis, \& cogerentur fateri errorem praeceptoris: vana, \& inepta omnino adduxerunt."

${ }^{69}$ Cabeo, In libros Meteorologicorum, vol. 4, 418: "Sed etiam hic videtur Aristoteles magis metaphysicis speculationibus assuetus, quam physicis observationibus." See also vol. 4, 79-80: "unde cum Aristoteles physicum agit, omnino antiquos sequitur, sed quia iste Philosophus maxime pollebat ingenio metaphyscio, \& apprime arridebat philosophari per metaphysicas abstractiones, reducendo semper res ad universalissimas, \& metaphysicas rationes, ut constat in tota eius physica; imo \& in tota morali, \& poetica, \& rhetorica ipsa; semper enim res deducit ad differentias, divisiones, \& metaphysicas abstractiones."

${ }^{70}$ Cabeo, In libros Meteorologicorum, vol. 4, 352: "Sed istos libros non legunt multi peripatetici occupati in illis subtilitatibus metaphysicis."

71 Newman, "Art, nature, and experiment," 305-317.

${ }^{72}$ Cabeo, In libros Meteorologicorum, vol. 4, 244: "puto illos [Chimicos] esse veros Philosophos physicos, qui ex propriis principiis rerum naturas venantur. nec potest quis melius scire, ex quibus nam res constent, tamquam ex elementis, quam si res ipsas dissolvat, \& partes componentes disiungat." 
Aristotle's position, which did not take into account the power of corrosive liquids. ${ }^{73}$ Believing that true physicists should rely on their own observations and not merely repeat what they have heard or read, he appeared to have conducted his own laboratory research. $\mathrm{He}$ described Geber's method for purging mercury in detail and called its preparation easy and within the bounds of philosophical research. ${ }^{74}$ For Cabeo, this method was the key to the transmutation of metals because of its description of the production of the "Mercury of Philosophers" (Mercurius Philosophorum) that, with the proper fermentation, can be made into true metals. ${ }^{75}$

Cabeo aimed to reconcile alchemical teachings with more traditional Peripatetic thought. For example, in his comments on Meteorologica I, he attempted to show that the sulfur, salt and mercury theory of matter held by alchemists, including Paracelsus, ${ }^{76}$ corresponded to the dual exhalations. Under his interpretation the two exhalations can be defined as being wet and dry respectively, or alternatively as watery and full of spirit (spiritosa). He identified the watery exhalation with mercury, and sulfur with spirit: the wet, in Aristotelian terms, which alchemists call mercury, acts as a chain and bind through which sulfur, the spirited active part combines with salt, the part of the mixture that persists and gives stability to the compound. ${ }^{77}$ The views of the alchemists, according to Cabeo, are not novelties, but rather based on ancient learning and are found in ancient texts. ${ }^{78}$ Accordingly, he cited De generatione et corruptione where Aristotle argued that earth without moisture can not hold itself together. ${ }^{79}$ The experiments of alchemists, themselves antique, further support the wisdom of ancient texts.

${ }^{73}$ Cabeo, In libros Meteorologicorum, vol. 4, 359: "Aes vero est quidem liquabile ex quo videtur humectabile; at non est liquabile aqua. sed non vidit Aristoteles aquas corrosivas. .."

${ }^{74}$ Cabeo, In libros Meteorologicorum, vol. 4, 356: "Geber ponit modum purgandi Mercurium facilem, $\&$ paratum quem pono hic.... Haec tamen praeparatio facilis est, nec videtur mihi a Philosophia nec abhorrere;" For Geber's instructions see: Newman, The Summa Perfectionis, 385-390.

75 Cabeo, In libros Meteorologicorum, vol. 4, 356-7.

${ }^{76}$ For the availability and diffusion of Paracelsus's writings in Italy see Marco Ferrari, "Alcune vie di diffusione in Italia di idee di testi di Paracelso," in Scienze, credenze occulte, livelli di cultura (Florence: Olschki, 1982), 21-9.

77 Cabeo, In libros Meteorologicorum, vol. 1, 113: "Quaeret aliquis cur Aristoteles non distinxerit haec effluvia, ut Chymici sapientiores, in sensitiva, vegetabilia, \& mineralia? sed revocet potius ad duo genera vaporum scilicet, \& exhalationum? Respondeo hoc sapientissime factum; revera enim in tota arte sublimatoria, quae unica Meteora docere potest, duo constat esse genera effluviorum, quae ascendunt: humida, $\&$ sicca, seu aquea, $\&$ spiritosa. quamvis enim postea singula istorum generum in diversas dividantur differentias; tamen omnia in hoc conveniunt, ut aliqua humida, aliqua sicca, seu spiritosa, \& hoc fortasse sibi voluerunt Chymici, dum dixerunt, omnia, quae usquam hic apud nos sunt, continere, praeter salem, hoc est praeter fixam illam partem, quae non ascendit, nec resolvitur in effluvium, sed semper remanet gravis, \& cadens; continere duas partes sulphurem scilicet, \& Mercurium, \& in his duabus partibus omnia resolvi; nec repugnabit quicunque Philosophiam ex sensu addiscit, si Mercurii nomine intelligat partem aqueam, seu humidam, qua res omnes continuantur, $\&$ cohaerent, $\&$ nomine sulphuris intelligat spiritum, seu partem spiritosam, subtilem, vividam, activam, formalem."

78 Cabeo, In libros Meteorologicorum, vol. 1, 113: "Verba haec tibi suspicionem non ingerant novitatis, rem tene, quae antiqua, imo antiquissima est, \& communis."

${ }^{79}$ Cabeo, In libros Meteorologicorum, vol. 1, 114: "Humiditas ergo, quam, si non haberes aliam vocem, a Chymicorum vocibus vocabis Mercurium, est vinculum illud, \& ligamen, quo sulphur, hoc est spiritosa, \& vivida illa pars, quae in resolutione abit in auras, \& subtile effluvium, 


\section{Conclusion}

While Meteorologica IV was of much interest to early modern alchemical writers, Renaissance commentators on this work showed little interest in fully developing the significance of this work to alchemy. Unlike medicine, alchemy was not a standard part of university curricula, and while many professors of natural philosophy taught or were trained in medicine, few commentators on Meteorologica IV appeared to have dedicated themselves to persistent investigations in this field. The few topoi that were discussed with reference to alchemy were discussed in the framework of medieval authors, who were probably more knowledgeable in this field. While a small number of Renaissance commentators correctly pointed out the utility of Meteorologica IV to alchemy, for the most part their lack of experience in this field limited the degree to which they showed this utility. It was not until the 1630s and 1640s that we find the crepuscular Peripatetics Trimarchi and Cabeo writing treatments of this work that are deeply integrated with alchemy. Trimarchi's work, however, is scarcely derivative of Aristotle's views and reveals the demands of making Aristotelian natural philosophy a complete science, more than how Meteorologica IV is applicable to alchemy. As a result, it did not represent a true application of the text towards a practical utility. Cabeo, on the other hand, instead of applying Aristotle to alchemy, applied alchemy to Aristotle. In his eyes the utility of natural philosophy was less significant than the utility of the craft of alchemy to natural philosophy, and a literal reading of Aristotle could not yield a viable theory of nature unless combined with experiment and experience.

\section{Acknowledgments}

I am grateful for the comments and suggestions made by Katharine Park, Bill Newman, John Murdoch and an anonymous reviewer. My research was made possible through support from the Gladys Krieble Delmas Foundation.

79 continued

coniungitur cum sale, hoc est cum parte illa fixa, stabili, \& consistente, quae semper remanet, \& in perfecta resolutione nunquam resolutione nunquam resolvitur. Neque alienus erit Aristoteles ab hac doctrina, qui 2. de Gen. Tex. 49 dicit per hoc probari, in quolibet mixto esse humidum, quia terra sine humido non potest consistere; sed hoc est, quod continet." Cf. De generatione et corruptione, 334b34-335a3. 


\section{Author Query Sheet}

Manuscript Information

Journal Acronym AMB

Volume and issue $\quad 51 / 3$

Author name: Craig Martin

Manuscript No.

QUERY NO.

1

2
QUERY DETAILS

Are there any editor(s) details?

Editor details? 